\title{
Carcass traits of feedlot crossbred lambs slaughtered at different live weights
}

\author{
Características da carcaça de cordeiros cruzados, confinados e abatidos em diferentes pesos
}

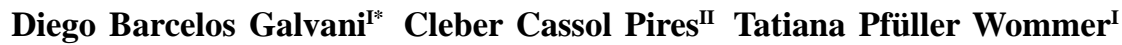 \\ Franciele de Oliveira ${ }^{\mathrm{III}}$ Anderson Michel Soares Bolzan ${ }^{\mathrm{III}}$ Poliana François $^{\mathrm{I}}$
}

\begin{abstract}
Carcass traits of twenty Texel x Ile de France crossbred lambs slaughtered after weaning (52 days of age), or at 25,30 and $35 \mathrm{~kg}$ live weight were evaluated. Lambs were placed in individual stalls $\left(1.5 \mathrm{~m}^{2}\right)$ and fed ad libitum with a diet composed of sorghum silage (Sorghum bicolor (L.) Moench) and a concentrate mix (ground corn, soybean meal, calcium carbonate and salt). Commercial dressing percentage was related quadratically with slaughter weight, being highest in lambs slaughtered after weaning. Real dressing percentage increased linearly. Shoulder proportion decreased with slaughter weight, whereas leg, rib and neck proportions remained constant. Carcass fat was positively correlated to the slaughter weight. Slaughter of feedlot Texel $x$ Ile de France crossbred lambs can be recommended at $28 \mathrm{~kg}$ live weight.
\end{abstract}

Key words: carcass composition, dressing percentage, fat, shoulder.

\section{RESUMO}

Foram avaliadas as características da carcaça de cordeiros Texel x Ile de France abatidos após o desmame (52 dias de idade) ou aos 25, 30 e $35 \mathrm{~kg}$ de peso vivo. Utilizaramse 20 cordeiros, confinados em baias individuais $\left(1,5 \mathrm{~m}^{2}\right) e$ alimentados ad libitum com dieta composta por silagem de sorgo (Sorghum bicolor (L.) Moench) e mistura concentrada (grão de milho triturado, farelo de soja, calcário calcítico e sal comum). O rendimento de carcaça comercial relacionou-se quadraticamente ao peso de abate, sendo máximo para os animais abatidos após o desmame. O rendimento de carcaça real elevou-se linearmente. Foi observado decréscimo linear da proporção de paleta à medida que se elevou o peso de abate, ao passo que as proporções de perna, costela e pescoço permaneceram constantes. A proporção total de gordura da carcaça foi positivamente correlacionada ao peso de abate.
Recomenda-se que o abate de cordeiros Texel x Ile de France confinados seja realizado aos $28 \mathrm{~kg}$ de peso vivo.

Palavras chave: composição da carcaça, rendimento de carcaça, gordura, paleta.

\section{INTRODUCTION}

Improvement in sheep production systems, resulting in low fat carcasses, has stimulated demand for lamb meat. However, the diversity of breeds used in current production systems has resulted in large differences between carcass types (CUNHA et al., 2000), increasing difficulties in offering a standardized product. Carcass traits are affected by slaughter weight (PÉREZ et al., 2007) and mature size (LAMBE et al., 2007). Therefore, optimal slaughter weight is specific for each genotype, and its determination can help in obtaining carcasses of similar characteristics.

The Texel breed is popular as a terminal sire (LAMBE et al., 2007) and usually has been crossed with other breeds as it presents leaner carcass and higher lean to bone and lean to fat ratios when compared to other breeds (JONES et al., 2002). Texel x Ile de France crossing has been widely diffused to produce lambs with higher growth rates (PIRES et al., 2006). Nevertheless, the optimal slaughter weight for this genotype is not known.

The aim of this study was to evaluate changes in carcass traits according to slaughter weight

IPrograma de Pós-graduação em Zootecnia, Universidade Federal de Santa Maria (UFSM), 97105-900, Santa Maria, RS, Brasil. Email: dbg@mail.ufsm.br.*Autor para correspondência.

IIDepartamento de Zootecnia, UFSM, Santa Maria, RS, Brasil.

IIICurso de Zootecnia, UFSM, Santa Maria, RS, Brasil. 
and to determine an ideal slaughter weight for feedlot Texel x Ile de France crossbred lambs.

\section{MATERIAL AND METHODS}

The experiment was carried out from September to December 2006, in the Sheep Division of the Universidade Federal de Santa Maria (UFSM), located in Santa Maria (2943’S, 5342’W, 95 m a.s.l.), RS, Brazil.

Twenty Texel x Ile de France crossbred noncastrated male lambs, weaned at 42 days of age (15.9 \pm $2.1 \mathrm{~kg}$ live weight (LW)) were used. Lambs were separated from their dams, treated for internal parasites, and placed in individual stalls $\left(1.5 \mathrm{~m}^{2}\right)$ equipped with feeders and water ad libitum. After ten days of management and diet adaptation five lambs were randomly chosen, weighed and slaughtered (slaughter after weaning group - SW). Remaining animals were then randomly assigned to one of three slaughter weights: 25 (S25), 30 (S30) or 35 (S35) kg live weight.

Diet was composed of sorghum silage (Sorghum bicolor (L.) Moench) and a concentrate mix (ground corn, soybean meal, calcium carbonate and salt), and formulated according to NRC (1985) recommendations to provide a daily LW gain of $200 \mathrm{~g}$ animal $^{-1}$. Animals were fed ad libitum twice daily at 08:00 and 16:00h. Roughage and concentrate were weighed individually and mixed immediately before feeding. The feed was adjusted daily to ensure $10 \%$ refusal. Chemical analyses of the diet were performed according to AOAC (1995) and ROBERTSON \& VAN SOEST (1981). Diet formulation and chemical composition of roughage, concentrate and total mixed ration (TMR) are shown in table 1.

Lambs were slaughtered after a 16-hour fasting period. Before slaughter animals were electrically stunned. The head was separated from the carcass at the atlanto-occipital joint; forelegs were split by cutting between the carpus and metacarpus, and the hind legs cut between the tarsus and metatarsus. Carcasses were weighed (hot weight), chilled at $2^{\circ} \mathrm{C}$ for 24 hours and reweighed (cold weight). The gastrointestinal content was estimated as the difference between full and empty gastrointestinal tract weight, and the empty body weight by difference between slaughter weight and gastrointestinal content. Commercial dressing percentage (hot carcass weight/ slaughter weight), real dressing percentage (hot carcass weight/empty body weight), and cooling loss index ([hot carcass weight - cold carcass weight]/hot carcass weight) were calculated. Chilled carcasses were split in the dorsal midline and cut between $12^{\text {th }}$ and $13^{\text {th }}$
Table 1 - Ingredients and chemical composition of the experimental diet.

\begin{tabular}{lccc}
\hline Ingredient (\%) & \multicolumn{2}{c}{ TMR Composition (DM) ${ }^{\mathrm{a}}$} \\
\hline Sorghum silage & & 55.0 & \\
Ground corn & & 20.7 & \\
Soybean meal & & 23.2 & \\
Calcium carbonate & & 0.85 & \\
Salt & & 0.25 & \\
& Roughage & Concentrate & TMR \\
Dry matter (\%) & 34.6 & 80.8 & 46.6 \\
Composition (\% of DM) & & & \\
Organic matter & 95.5 & 93.9 & 94.8 \\
Crude protein & 6.6 & 30.6 & 17.4 \\
Neutral detergent fiber & 47.4 & 9.9 & 30.6 \\
Acid detergent fiber & 24.8 & 3.7 & 15.3 \\
Lignin & 3.4 & 0.4 & 2.0 \\
Ether extract & 2.6 & 3.0 & 2.8 \\
Non-structural carbohydrate & 39.7 & 51.2 & 44.9 \\
\hline
\end{tabular}

a Total mixed ration on dry matter basis.

ribs to estimate subcutaneous fat thickness. The righthalf carcass was divided into shoulder, neck, rib and leg according to OSÓRIO et al. (1998). Individual cuts were then dissected into muscle, bone and total fat contents.

Data were analyzed as a fully randomized design by regression analysis that included linear and quadratic effects, taking observed slaughter weight as an independent variable. Comparison of the tissue composition among individual cuts, within each slaughter group, was carried out using the Tukey test. Some correlation coefficients were obtained. All statistical procedures were performed at a $5 \%$ significance level using the Statistical Analysis System (SAS, 2004)

\section{RESULTS AND DISCUSSION}

Fixed slaughter weights were reached at 52 , 87, 106 and 117 days of age for SW, S25, S30 and S35, respectively. Results of the main carcass characteristics are presented in table 2. Cooling loss index was not affected $(\mathrm{P}>0.05)$ but hot and cold carcass weights, as well as real dressing percentage increased linearly with increased slaughter weight $(\mathrm{P} \leq 0.01)$. Commercial dressing percentage and subcutaneous fat thickness, however, were related quadratically $(\mathrm{P}<0.001)$ to slaughter weight, being highest for lambs slaughtered after weaning (SW).

Commercial dressing percentage has been shown to be related with digestive tract content, and carcass fatness, which are affected by slaughter weight 
Table 2 - Mean values for slaughter weight, carcass weights, dressing percentage, cooling loss index, and subcutaneous fat thickness according to slaughter weight of crossbred Texel x Ile de France lambs.

\begin{tabular}{|c|c|c|c|c|c|c|c|c|}
\hline \multirow{3}{*}{ Variable } & \multicolumn{4}{|c|}{--------------------Groups a ------------------- } & \multirow{3}{*}{$\mathrm{SE}^{\mathrm{b}}$} & \multirow{3}{*}{$r^{2}$} & \multicolumn{2}{|c|}{---P-value ${ }^{\mathrm{c}}---$} \\
\hline & & & & & & & & \\
\hline & SW & S25 & S30 & S35 & & & $\mathrm{L}$ & Q \\
\hline Slaughter weight (kg) & 17.300 & 25.540 & 30.620 & 35.400 & 0.19 & --- & $* * *$ & ns \\
\hline Hot carcass weight (kg) & 8.491 & 11.330 & 14.088 & 16.534 & 0.11 & 0.98 & $* * *$ & ns \\
\hline Cold carcass weight (kg) & 8.239 & 10.996 & 13.644 & 16.069 & 0.11 & 0.97 & $* * *$ & ns \\
\hline Commercial dressing percentage (\%) & 49.12 & 44.37 & 46.13 & 46.71 & 0.31 & 0.67 & ns & $* * *$ \\
\hline Real dressing percentage (\%) & 56.03 & 55.42 & 57.63 & 57.33 & 0.21 & 0.38 & $* *$ & ns \\
\hline Cooling loss index (\%) & 2.97 & 2.95 & 3.16 & 2.81 & 0.07 & 0.06 & ns & ns \\
\hline Subcutaneous fat thickness (mm) & 0.66 & 0.88 & 1.32 & 2.33 & 0.10 & 0.72 & ns & $* * *$ \\
\hline
\end{tabular}

${ }^{a}$ Groups: SW - slaughter after weaning; S25 - slaughter at 25kg LW; S30 - slaughter at 30kg LW; S35 - slaughter at35 kg LW; (LW - live weight).

b Standard error of the means.

${ }^{c}$ Probability of either linear (L) or quadratic (Q) effect, where: ns - non significant, $* * P<0.01$ and $* * * P<0.001$.

(OWENS et al., 1995; KREMER et al., 2004). In the present study the correlation coefficient $(r)$ between commercial dressing percentage and gastrointestinal content (12.33, 19.29, 19.20 and $18.52 \%$, respectively for SW, S25, S30 and S35) was -0.87. Low gastrointestinal content for SW can be related to lack of rumen development and, consequently, to low intake of a solid diet (PIRES et al., 2000; KREMER et al., 2004). Otherwise, commercial dressing percentage increases as slaughter weight increases and it is related to high rate of fat deposition at maturity (ROSA et al., 2005). REID \& ROBB (1971) speculated that accumulation of fat reduces the volume available for the digestive tract and, consequently, would decrease feed intake and gastrointestinal content. In fact, more recent studies have suggested that feed intake decreases as fat accretion, but it is due to higher leptin secretion by adipose tissue (INGVARTSEN \& BOISCLAIR, 2001; EHRHARDT et al., 2003). However, in our study different feed intake among the groups evaluated was not verified $(\mathrm{P}>0.05)$, suggesting that highest fat deposition at more elevated slaughter weights, as indicated by increased subcutaneous fat thickness, is the mainly characteristic determining the commercial dressing percentage.

Real dressing percentage, as opposed to commercial dressing percentage, was not affected by gastrointestinal content $(\mathrm{r}=0.09 ; \mathrm{P}=0.71)$ and increased with slaughter weight. This maybe due to the rate of carcass growth being higher than the rate of viscera growth (PIRES et al., 2000; VELASCO et al., 2000).

The cooling loss index, which represents the weight loss due water losses during carcass refrigeration (PIRES et al., 2006), is inversely related to subcutaneous fatness (CAÑEQUE et al., 2004). However, in our study, the highest subcutaneous fat thickness observed in lambs slaughtered at higher weights did not affect cooling losses, suggesting that approximately $0.7 \mathrm{~mm}$ of subcutaneous fat thickness is sufficient to protect lamb carcasses from water losses during cool storage. Results of this study are consistent with those reported by HUIDOBRO \& CAÑEQUE (1993a) and PIRES et al. (2006).

Weights of all cuts increased with slaughter weight $(\mathrm{P}<0.001)$ (Table 3). Otherwise, the proportion of shoulder decreased linearly $(\mathrm{P}<0.001)$, whereas the proportions of the remaining cuts were not affected by slaughter weight. Proportion of individual cuts has been shown to be related with slaughter weight due to variation in muscle, bone and, mainly, fat tissue contents (SILVA et al., 2000b). In contrast with our results, HUIDOBRO \& CAÑEQUE (1993b) reported that leg and shoulder proportions in Manchega lambs decreased and rib proportion increased with slaughter weight. SILVA et al. (2000b) reported increases only in rib proportion in Texel x Polwarth crossbred lambs, reaffirming the late maturity of the rib (OSÓRIO et al., 1997) related to fatness increase. Nevertheless, genotypes evaluated by those authors present higher proportion of fat in the carcass, when compared to breeds used in the present study, which has high capacity for meat production (PÉREZ et al., 1993; JONES et al., 2002). Leg, a high quality cut (DÍAZ et al., 2002), represented the largest of all individual cuts. According to HUIDOBRO \& CAÑEQUE (1993b), the proportions of the cuts can be utilized to establish the 
Table 3 - Means for weights and proportions of individual cuts according to slaughter weight for crossbred Texel x Ile de France lambs.

\begin{tabular}{|c|c|c|c|c|c|c|c|c|}
\hline \multirow{2}{*}{ Variable } & \multicolumn{4}{|c|}{------------------------Groups a ------------------------ } & \multirow{2}{*}{$\mathrm{SE}^{\mathrm{b}}$} & \multirow{2}{*}{$r^{2}$} & \multicolumn{2}{|c|}{$P$-value ${ }^{\mathrm{c}}$} \\
\hline & SW & $\mathrm{S} 25$ & S30 & S35 & & & $\mathrm{L}$ & $\mathrm{O}$ \\
\hline Leg (kg) & 1.440 & 1.974 & 2.436 & 2.818 & 0.02 & 0.98 & $* * *$ & ns \\
\hline Shoulder (kg) & 0.890 & 1.109 & 1.426 & 1.586 & 0.02 & 0.94 & $* * *$ & ns \\
\hline Rib (kg) & 1.405 & 1.885 & 2.407 & 2.806 & 0.03 & 0.96 & $* * *$ & ns \\
\hline Neck (kg) & 0.341 & 0.469 & 0.627 & 0.707 & 0.01 & 0.92 & $* * *$ & ns \\
\hline Leg (\%) & 35.27 & 36.32 & 35.32 & 35.59 & 0.19 & 0.02 & ns & ns \\
\hline Shoulder (\%) & 21.81 & 20.40 & 20.69 & 20.03 & 0.14 & 0.57 & $* *$ & ns \\
\hline Rib (\%) & 34.50 & 34.65 & 34.90 & 35.44 & 0.21 & 0.09 & ns & ns \\
\hline Neck (\%) & 8.04 & 8.62 & 9.09 & 8.93 & 0.14 & 0.11 & ns & ns \\
\hline
\end{tabular}

${ }^{\text {a }}$ Groups: SW - slaughter after weaning; S25 - slaughter at 25kg LW; S30 - slaughter at 30kg LW; S35 - slaughter at 35kg LW; (LW - live weight).

${ }^{\mathrm{b}}$ Standard error of the means.

${ }^{\mathrm{c}}$ Probability of either linear (L) or quadratic (Q) effect, where: ns - non significant, $* * P<0.01$ and $* * * P<0.001$.

commercial value of the carcass. Therefore, the non significant effect of slaughter weight on the leg proportions may indicate a same valorization for all carcass types described in this study. However, the increased rib fat (13.7 to $24.7 \%$ ) observed is a depreciative characteristic of the carcass (HUIDOBRO \& CAÑEQUE, 1993b).

The contents of muscle, bone and fat, as well as fat proportion of the carcass increased while muscle and bone proportions decreased linearly with increased slaughter weight $(\mathrm{P}<0.001)$ (Table 4). Similar results were reported by VELASCO et al. (2000), DÍAZ et al. (2006) and PIRES et al. (2006). In our study, muscle proportions were higher than those reported by CUNHA et al. (2001) and PÉREZ et al. (2007) who evaluated carcass characteristics of other genotypes (Suffolk, Merino Precoz Aleman, Suffolk x Corriedale and Suffolk x Merino Precoz Aleman). In addition, total fat proportion of the carcass was positively correlated with subcutaneous fat thickness $(\mathrm{r}=0.84)$.

Table 5 shows the mean values of muscle, bone and fat proportions in individual cuts, at the different slaughter weights. All cuts presented a linear increase in fat, whereas bone proportions decreased linearly with increased slaughter weight $(\mathrm{P}<0.001)$. Muscle proportions decreased in the rib and neck $(\mathrm{P}<0.001)$, but tehy were not affected by slaughter weight in leg and shoulder. The muscle proportion was highest for the leg (70.3\%), followed by shoulder (65.2\%) and rib (61.3\%). Neck (24.4\%) and rib (20\%) presented the highest proportions of fat, while leg showed the lowest one proportion. Bone proportions were consistent among cuts. Rib and neck presented the greatest fat

Table 4 - Means for weights and proportions of muscle, bone and fat in the carcass according to slaughter weight for crossbred Texel x Ile de France lambs.

\begin{tabular}{|c|c|c|c|c|c|c|c|c|}
\hline \multirow{2}{*}{ Variable } & \multicolumn{4}{|c|}{--------------------------'Groups } & \multirow{2}{*}{$\mathrm{SE}^{\mathrm{b}}$} & \multirow{2}{*}{$r^{2}$} & \multicolumn{2}{|c|}{----P-value ${ }^{\mathrm{c}}$---- } \\
\hline & SW & S25 & S30 & S35 & & & $\mathrm{L}$ & $\mathrm{Q}$ \\
\hline Muscle (kg) & 2.702 & 3.572 & 4.459 & 4.977 & 0.05 & 0.94 & $* * *$ & ns \\
\hline Bone (kg) & 0.890 & 1.030 & 1.193 & 1.369 & 0.02 & 0.89 & $* * *$ & ns \\
\hline Fat $(\mathrm{kg})$ & 0.484 & 0.836 & 1.244 & 1.572 & 0.03 & 0.93 & $* * *$ & ns \\
\hline Muscle (\%) & 66.24 & 65.67 & 64.60 & 62.86 & 0.51 & 0.27 & $* * *$ & ns \\
\hline Bone (\%) & 21.84 & 18.93 & 17.35 & 17.29 & 0.28 & 0.74 & $* * *$ & ns \\
\hline Fat (\%) & 11.90 & 15.41 & 18.04 & 19.85 & 0.40 & 0.76 & $* * *$ & ns \\
\hline
\end{tabular}

${ }^{a}$ Groups: SW - slaughter after weaning; S25 - slaughter at 25kg LW; S30 - slaughter at 30kg LW; S35 - slaughter at 35kg LW; (LW - live weight).

${ }^{\mathrm{b}}$ Standard error of the means.

${ }^{\mathrm{c}}$ Probability of either linear (L) or quadratic (Q) effect, where: ns - non significant and ${ }^{* * *} P<0.001$.

Ciência Rural, v.38, n.6, set, 2008. 
Table 5 - Mean values for muscle, bone and fat proportions of the individual cuts according to slaughter weight for crossbred Texel x Ile de France lambs.

\begin{tabular}{|c|c|c|c|c|c|c|c|c|}
\hline \multirow{3}{*}{ Variable } & \multicolumn{4}{|c|}{ 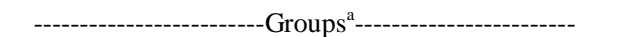 } & \multirow{3}{*}{$S E^{b}$} & \multirow{3}{*}{$r^{2}$} & \multicolumn{2}{|c|}{----P-value ${ }^{\mathrm{c}}----$} \\
\hline & & & & & & & & \\
\hline & SW & S25 & S30 & S35 & & & $\mathrm{L}$ & Q \\
\hline \multicolumn{9}{|l|}{ Leg } \\
\hline Muscle (\%) & $70.60^{\mathrm{a}}$ & $70.84^{\mathrm{a}}$ & $70.66^{\mathrm{a}}$ & $69.20^{\mathrm{a}}$ & 0.47 & 0.10 & ns & ns \\
\hline Bone (\%) & 20.96 & $18.99^{\mathrm{ab}}$ & 16.96 & 16.78 & 0.32 & 0.64 & $* * *$ & ns \\
\hline Fat (\%) & $8.44^{\mathrm{c}}$ & $10.16^{\mathrm{c}}$ & $12.38^{\mathrm{d}}$ & $14.02^{\mathrm{c}}$ & 0.34 & 0.71 & $* * *$ & ns \\
\hline \multicolumn{9}{|l|}{ Shoulder } \\
\hline Muscle (\%) & $65.94^{\mathrm{ab}}$ & $65.17^{\mathrm{b}}$ & $65.02^{\mathrm{b}}$ & $64.55^{\mathrm{a}}$ & 0.51 & 0.05 & ns & ns \\
\hline Bone (\%) & 21.33 & $20.07^{\mathrm{a}}$ & 18.21 & 18.62 & 0.27 & 0.61 & $* * *$ & ns \\
\hline Fat (\%) & $12.73^{\mathrm{b}}$ & $14.75^{\mathrm{b}}$ & $16.77^{\mathrm{c}}$ & $16.83^{\mathrm{c}}$ & 0.39 & 0.56 & $* * *$ & ns \\
\hline \multicolumn{9}{|l|}{ Rib } \\
\hline Muscle (\%) & $63.62^{\mathrm{bc}}$ & $62.17^{\mathrm{bc}}$ & $61.12^{\mathrm{b}}$ & $58.35^{\mathrm{b}}$ & 0.62 & 0.36 & $* * *$ & ns \\
\hline Bone (\%) & 22.71 & $17.94^{\mathrm{b}}$ & 17.23 & 16.95 & 0.37 & 0.75 & $* * *$ & ns \\
\hline Fat (\%) & $13.67^{\mathrm{ab}}$ & $19.88^{\mathrm{a}}$ & $21.64^{\mathrm{b}}$ & $24.70^{\mathrm{b}}$ & 0.60 & 0.72 & $* * *$ & ns \\
\hline \multicolumn{9}{|l|}{ Neck } \\
\hline Muscle (\%) & $59.76^{\mathrm{c}}$ & $58.90^{c}$ & $53.61^{\mathrm{c}}$ & $51.76^{\mathrm{c}}$ & 0.80 & 0.55 & $* * *$ & ns \\
\hline Bone (\%) & 23.22 & $19.86^{\mathrm{ab}}$ & 17.47 & 17.71 & 0.51 & 0.57 & $* * *$ & ns \\
\hline Fat (\%) & $17.01^{\mathrm{a}}$ & $21.24^{\mathrm{a}}$ & $28.91^{\mathrm{a}}$ & $30.51^{\mathrm{a}}$ & 0.69 & 0.82 & $* * *$ & ns \\
\hline
\end{tabular}

Means followed by different letters in the same column differ into tissue proportion $(P<0.05)$.

${ }^{a}$ Groups: SW - slaughter after weaning; S25 - slaughter at 25kg LW; S30 - slaughter at 30kg LW; S35 - slaughter at 35kg LW; (LW - live weight).

b Standard error of the means.

${ }^{c}$ Probability of either linear (L) or quadratic (Q) effect, where: ns - non significant and $* * * P<0.001$.

deposition with increased slaughter weight (80.7 and $79.4 \%$, respectively).

Estimated regression equations for carcass muscle, bone and total fat proportions, as a function of slaughter weight, are presented in figure 1. According to OSÓRIO (1992), better carcasses present higher muscle and lower bone proportions, and fat content should be just enough to protect the carcass during refrigeration and for maintenance of the sensory characteristics of the meat. In this sense, for Ile de France x Corriedale crossbred lambs, SIQUEIRA et al. (2001) recommended slaughter weight at $28 \mathrm{~kg}$, when muscle, bone and fat proportions were about 60, 18 and $16 \%$, respectively. Similar proportions were obtained in this study, using regression equations, if lambs are slaughtered also at $28 \mathrm{~kg}$ live weight (64.7, 18.6 and $16.6 \%$, respectively for muscle, bone and fat proportions). Moreover, at this weight, rib fat content (20.4\%) can be considered acceptable and not depreciative for the carcass (SILVA et al., 2000a). The high muscle proportion observed in our study is a characteristic of Texel crossbred lambs (JONES et al., 2002).

Slaughter of lambs at lesser weights is not common in Brazil. However, it could represent an alternative for business opportunities such as those that occur, for example, in the European Union, mainly in the metropolitan regions, where the organoleptic qualities and low fat composition of that meat (DÍAZ et al., 2006), which is associated to human health, are highly appreciated.

\section{CONCLUSIONS}

Carcass traits are greatly modified by slaughter weight. Muscle and bone proportions in the carcass decreased, and total fat increased with slaughter weight. Individual cuts present different compositions; the rib is the cut with the highest fat deposition. Slaughter of feedlot Texel x Ile de France crossbred lambs can be recommended at $28 \mathrm{~kg}$ live weight.

\section{ACKNOWLEDGEMENTS}

To Conselho Nacional de Desenvolvimento Científico e Tecnológico (CNPq) and Coordenação de Aperfeiçoamento de Pessoal de Nível Superior (CAPES) than provided scholarships for Cleber Cassol Pires and Diego Barcelos Galvani. 


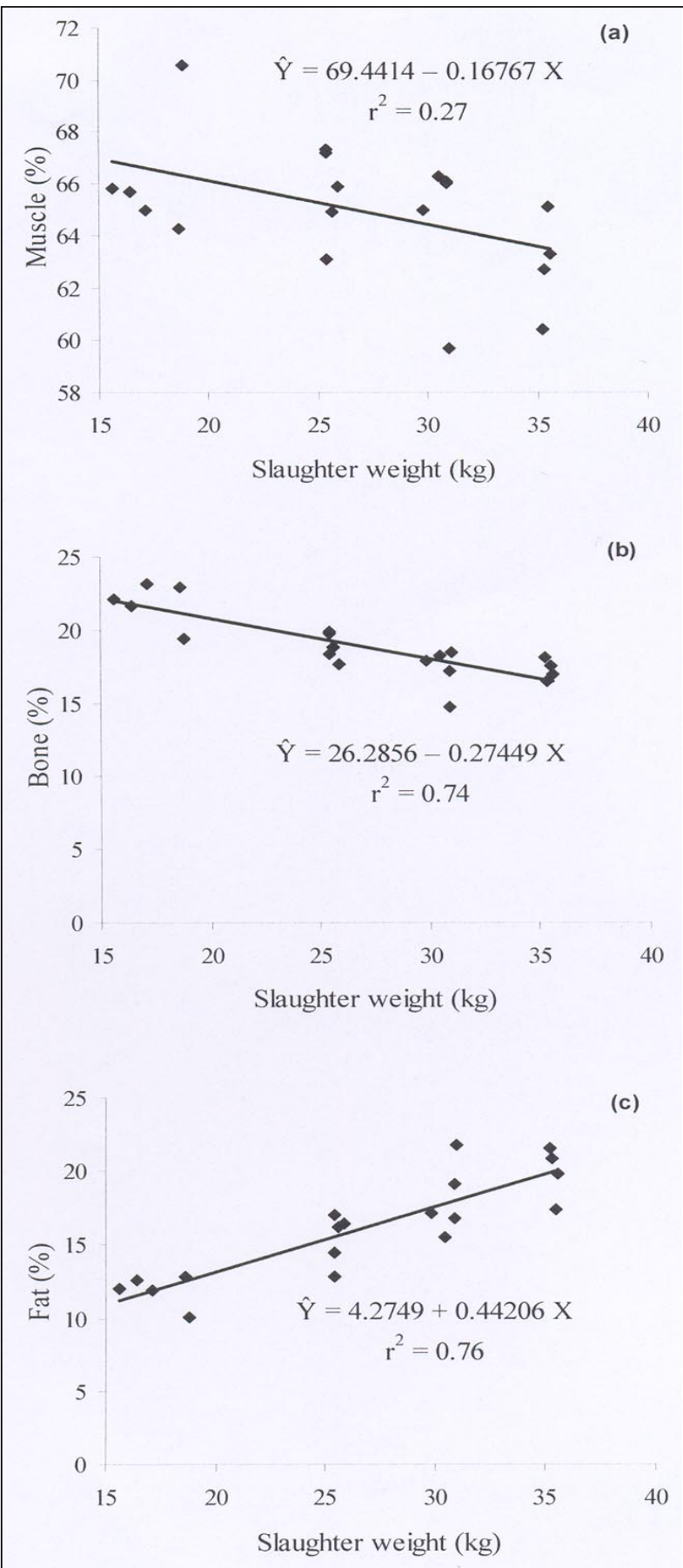

Figure 1 - Relationships between slaughter weight and muscle (a), bone (b) and fat (c) proportions in the carcass.

\section{REFERENCES}

ASSOCIATION OF OFFICIAL ANALYTICAL CHEMISTS AOAC. Official methods of analysis. 16.ed. Washington, D.C, $1995.1141 \mathrm{p}$.

CAÑEQUE, V. et al. Carcass and meat quality of light lambs using principal component analysis. Meat Science, v.67, p.595-605, 2004.
CUNHA, E.A. et al. Desempenho e características de carcaça de cordeiros Suffolk alimentados com diferentes volumosos. Ciência Rural, v.31, p.671-676, 2001.

CUNHA, E.A. et al. Utilização de carneiros de raças de corte para obtenção de cordeiros precoces para abate em plantéis produtores de lã. Revista Brasileira de Zootecnia, v.29, p.243-252, 2000.

DÍAZ, M.T. et al. Body composition in relation to slaughter weight and gender in suckling lambs. Small Ruminant Research, v.64, p.126-132, 2006.

DÍAZ, M.T. et al. Use of concentrate or pasture for fattening lambs and its effect on carcass and meat quality. Small Ruminant Research, v.43, p.257-268, 2002.

EHRHARDT, R.A. et al. Plasma leptin is regulated predominantly by nutrition in preruminant lambs. Journal of Nutrition, v.133, p.4196-4201, 2003.

HUIDOBRO, F.R.; CAÑEQUE, V. Producción de carne en corderos de raza Manchega. I. Estudio de los rendimientos en canal, de las perdidas en el matadero y de la importancia de los despojos. Investigación Agraria. Producción y Sanidad Animales, v.8, p.111-125, 1993a.

HUIDOBRO, F.R.; CAÑEQUE, V. Producción de carne en corderos de raza Manchega. II. Conformación y estado de engarzamiento de la canal y proporción de piezas en distintos tipos comerciales. Investigación Agraria. Producción y Sanidad Animales, v.8, p.233-243, 1993 b.

INGVARTSEN, K.L.; BOISCLAIR, Y.R. Leptin and the regulation of food intake, energy homeostasis and immunity with special focus on periparturient ruminants. Domestic Animal Endocrinology, v.21, p.215-250, 2001.

JONES, H.E. et al. Changes in muscularity with growth and its relationship with other carcass traits in three terminal sire breeds of sheep. Animal Science, v.74, p.265-275, 2002.

KREMER, R. et al. Effect of sire breed, year, sex and weight on carcass characteristics of lambs. Small Ruminant Research, v.53, p.117-124, 2004.

LAMBE, N.R. et al. Changes in carcass traits during growth in lambs of two contrasting breeds, measured using computer tomography. Livestock Science, v.107, p.37-52, 2007.

NATIONAL RESEARCH COUNCIL - NRC. Nutrient requirements of sheep. 6.ed. Washington, D.C.: National Academy, 1985. 112p.

OSÓRIO, J.C.S. Estudio de la calidad de canales comercializadas en el tipo ternasco según la procedencia: bases para la mejora de dicha calidad en Brasil. 1992. 355f. Tese (Doutorado em Veterinária) - Universidad de Zaragoza, Zaragoza.

OSÓRIO, J.C.S. et al. Métodos para avaliação da produção de carne ovina: in vivo, na carcaça e na carne. Pelotas: UFPEL, 1998. 98p.

OSÓRIO, J.C.S. et al. Produção de carne na raça Ideal. Pelotas: UFPEL, 1997. 57p. 
OWENS, F.N. et al. Review of some aspects of growth and development of feedlot cattle. Journal of Animal Science, v.73, p.3152-3172, 1995.

PÉREZ, J.I. et al. Efecto del tipo de destete, tipo de parto, genero y peso de la canal, en canales de corderos de raza Manchega. ITEA, v.12, p.648-650, 1993.

PÉREZ, P. et al. Gender and slaughter weight effects on carcass quality traits of suckling lambs from four different genotypes. Small Ruminant Research, v.70, p.124-130, 2007.

PIRES, C.C. et al. Características da carcaça de cordeiros alimentados com dietas contendo diferentes níveis de fibra em detergente neutro. Revista Brasileira de Zootecnia, v.35, p.2058-2065, 2006.

PIRES, C.C. et al. Crescimento de cordeiros abatidos com diferentes pesos. 2. constituintes corporais. Ciência Rural, v.30, p.869-873, 2000.

REID, J.T.; ROBB, J. Relationship of body composition to energy intake and energetic efficiency. Journal of Dairy Science, v.54, p.553-564, 1971.

ROBERTSON, J.B.; VAN SOEST, P.J. The detergent system of analysis. In: JAMES, W.P.T.; THEANDER, O. (Eds.). The analysis of dietary fiber in food. New York: Marcel Dekker, 1981. p.123-158.

ROSA, G.T. et al. Crescimento alométrico de osso, músculo e gordura em cortes da carcaça de cordeiros Texel segundo os métodos de alimentação e peso de abate. Ciência Rural, v.35, p.870-876, 2005.

STATISTICAL ANALISYS SYSTEM - SAS. SAS/STAT ${ }^{\circledR} \mathbf{9 . 1}$ User's guide. Cary, NC, 2004. 5135p

SILVA, L.F. et al. Crescimento de cordeiros abatidos com diferentes pesos. 1. Osso, músculo e gordura da carcaça e de seus cortes. Ciência Rural, v.30, p.671-675, 2000a.

SILVA, L.F. et al. Crescimento de regiões da carcaça de cordeiros abatidos com diferentes pesos. Ciência Rural, v.30, p.481$484,2000 \mathrm{~b}$.

SIQUEIRA, E.R. et al. Efeito do sexo e do peso ao abate sobre a produção de carne de cordeiro. Morfometria da carcaça, pesos dos cortes, composição tecidual e componentes não constituintes da carcaça. Revista Brasileira de Zootecnia, v.30, p.1299-1307, 2001

VELASCO, S. et al. Carcass and meat quality of Talaverana breed sucking lambs in relation to gender and slaughter weight. Animal Science, v.70, p.253-263, 2000. 